\title{
Population dynamics and infrastructure: meeting the millennium development goals in Ondo State, Nigeria
}

\author{
Allen, Abimbola Adebimpe \\ Department of Geography and Planning Sciences, Adekunle Ajasin University, \\ Akungba-Akoko,Ondo State, Nigeria, bimbomowo@yahoo.co.uk
}

\begin{abstract}
Population has become an important research issue because its consideration has significant implications for change, development and quality of life in the society. Infrastructure such as water, transport, drainage and sanitation on the other hand have been recognized as critical to ensure the quality of living and sustainable urban development in contemporary times. This paper examines the change in population growth of Ondo state with a view to determining the extent at which infrastructure in the study area has been improved on and what will be required to meet the MDGs for infrastructural development. The paper discusses the consequences of inadequate infrastructure in Ondo state as well as identifying how the MDGs targets can be achieved to reduce urban poverty in Africa. Data utilized in the study were derived from a systematic survey of household characteristics, indicators of accessibility to basic infrastructure in the city. Population figures were obtained from National Population Commission and distribution of regular households by main characteristics of infrastructure during the last census (2006) in Ondo State. The study showed that as is typical of a Nigerian State, the majority of residents of Ondo state do not have access to basic infrastructure.
\end{abstract}

Keywords: Population growth, health facilities, schools, environmental sustainability, Millennium Development Goals (MDGs)

\section{Résumé}

La population est devenue une édition de recherche importante parce que sa considération a des implications significatives pour le changement, le développement et la qualité de la vie dans la société. L'infrastructure comme l'eau, le transport, le drainage et le système sanitaire a d'autre part été reconnue d'autre part comme critique de garantir la qualité de vie et de développement urbain durable aux temps contemporains. Ce papier examine le changement dans la croissance démographique d'état d'Ondo avec une vue à la détermination de la mesure à laquelle l'infrastructure dans la région d'étude a été améliorée et ce qui sera tenu de rencontrer le MDGs pour le développement infrastructurel. Le papier discute les conséquences d'infrastructure insuffisante dans l'état d'Ondo aussi bien que s'identifie comment les cibles de MDGs peuvent être accomplies à la pauvreté urbaine réduite en Afrique. Les données utilisées dans l'étude ont provenu l'enquête systématique de caractéristiques du ménage, les indicateurs d'accessibilité à l'infrastructure fondamentale dans la ville. Les figures démographiques ont été obtenues de la Commission Démographique nationale et de la distribution de maisons régulières selon les caractéristiques principales d'infrastructure pendant le dernier recensement (2006) dans l'État Ondo. L'étude a montré que comme typique d'un État nigérian, la majorité des résidents d'état d'Ondo n'a pas d'approche à l'infrastructure fondamentale.

Mots clé : la croissance démographique, l'équipement de Santé, les Écoles, les Buts de Développement de Millénaire et de Sustainability de L'environnement (MDGs)

\section{Introduction}

In contemporary society, population has become an important research issue. This is so because population in terms of size, composition and dynamics has far-reaching implications for change, development and quality of life in the society. Population is a major asset or resource for development, and can be a major determinant of the strength of a country (Ranis et al., 2000). In the last few decades, population in Nigeria has increased annually by about 3.3\% (UNFPA, 1996), and this is expected to increase with immigration, natural increase and urbanization (Kuznets, 2003; Adeboyejo and Abolade, 
2006; United Nations, 2008). Effects of increasing population are many, and include increased vulnerability to environmental degradation and socio-economic problems, including high mortality and morbidity, especially in situations where urban increase cannot be commensurate with improvement in the social, economic and technological development (Martine and Marshall, 2007; Akinbode et al., 2008; Eludoyin and Adelekan, 2013). The need to improve the conditions of the rural and urban population in Nigeria and many other developing countries has been emphasized for some time. Globally, UNEP (2002) revealed that about 250 million people lack good water for domestic use, and another 400 million live under poor sanitation conditions. In Africa, it is estimated that over $70 \%$ of the urban population lack good housing and sanitation facilities (Cairncross, 1989; Nunan and Satterthwaite, 200 I ; Moe and Rheingans, 2006).

\section{Literature review and theoretical framework}

The recent global focus on the reduction of poverty and encouragement of the emancipation of the poor population, since the year 2000 through the Millennium Development Goals (MDGs) programmes (United Nations, 20I3) has been a subject of focus in the development plans of most countries, including Nigeria. The programmes for the MDGs are known to include: (I) eradication of extreme poverty and hunger, (2) achieving universal primary education; (3) promotion of gender equality and women's empowerment, (4) reduction of child mortality, (5) combating HIV/AIDS, malaria and other diseases, and (6) ensuring environmental sustainability (United Nations, 20I3).

Concerns about the impact of the problems that the MDGs are meant to tackle has been a subject of focus of many studies, especially in the light of inequality of resource allocation and use, gender imbalance, child and young mortality, diseases and unsustainable development (Redclift, 1992; Andersson and Linderoth, 200I; Chi, 2008). One concept that has been frequently used and is found relevant to this study is the Friedman's core-periphery model (Pepper, 1999).

According to the Friedman's model, the landscape of a society is made up of a core, resource base and periphery (Friedman, 1973). The resource base, usually the rural area with abundant natural resources, is exploited to develop the core, which often is an urban area or an administrative centre. Following continuous exploitation, the resource base becomes deprived and impoverished, and its inhabitants are less catered for at the expense of the 'core', which usually receives the 'lion's share' of the development. Subsequently, the rural areas are often characterised by economically poor and vulnerable inhabitants with inadequate or an absolute lack of social amenities, including good schools, electrical supply, good roads and markets, postal and commercial services; a condition that has encouraged intensive rural-urban migration. The developed centres often become overwhelmed in infrastructure and population problems because of unsustainably increasing numbers of migrants, and other forms of the backwash effects (Todaro, 1980; Oppong et al., 1988; Cohen, 2004). In Akure, which is the administrative centre of Ondo State, the influence of urbanisation has been noted to cause an urban heat island phenomenon in many areas, an event that can significantly affect the physical comfort of the people (Akinbode et al., 2008; Eludoyin and Adelekan, 2013).

In Nigeria, each of the 36 States has made provisions towards achieving the MDGs goals with assistance from different agencies, including the World Bank and other international organizations. This study therefore assesses the focus of Ondo State, in the Southwest Nigeria as an indicator for the performances of the States in the region. While the author accepts that developmental performance can be better assessed on individual State basis, the present study is a preliminary study and its results will form the basis for the planning of assessment for more States in the country. Specific objectives of the study are to (I) investigate the relationship that exists between population growth and infrastructure in the study area; and (2) examine the efforts aimed at achieving the MDGs in the area of infrastructural development in the region.

\section{Study Area}

Ondo State, which was created with seven 
other States on $3^{\text {rd }}$ February 1976 from the Western Region in Nigeria, is located between $5^{0} 45^{\prime} \mathrm{N}, 4^{0} 20^{\prime} \mathrm{E}$ and $7^{0} 52^{\prime} \mathrm{N}, 6^{\circ} 05^{\mathrm{I}} \mathrm{E}$ (Figure I). As at 2006, the population of the State was 3,460,877 (male population I,745,057 and female I, 7I5,820). Figure 2, which shows the population distribution of the State between 1970 and 2010, reveals an increasing trend. There are 18 local government areas, each with an administrative headquarter, and distributed into three senatorial districts, to ensure a wide spread of development. The capital city Akure and other large towns have also witnessed rapid population and structural growth, with the attendant negative environmental impacts in the recent years (Akinbode et al, 2008; Aguda et al., 2013).

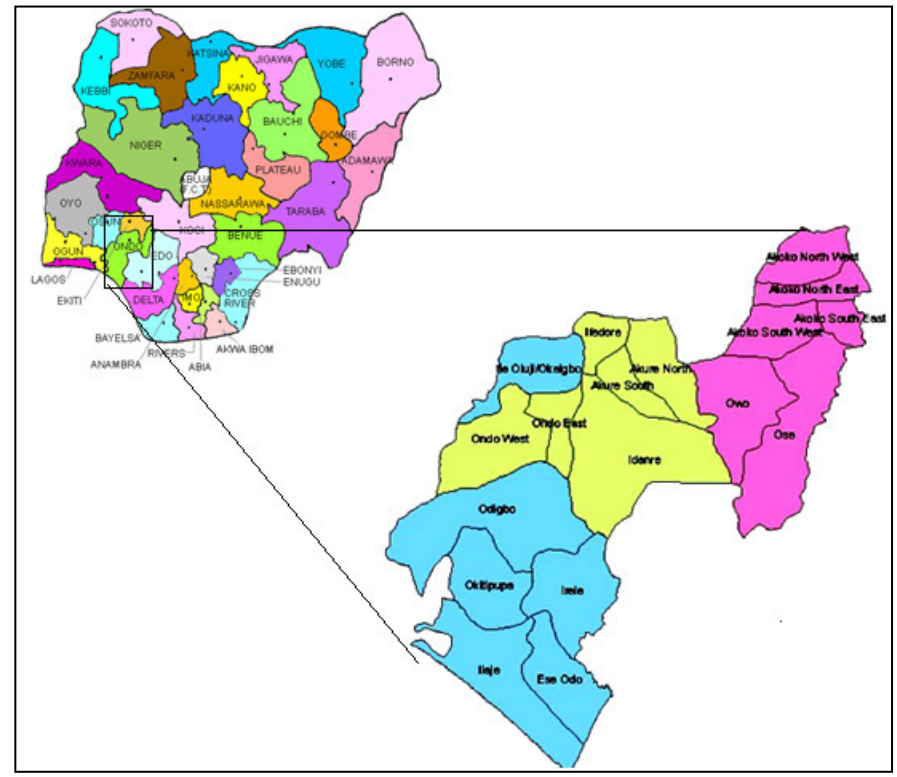

Figure 1. Ondo State in Nigeria. The colours in the states represent different Senatorial districts

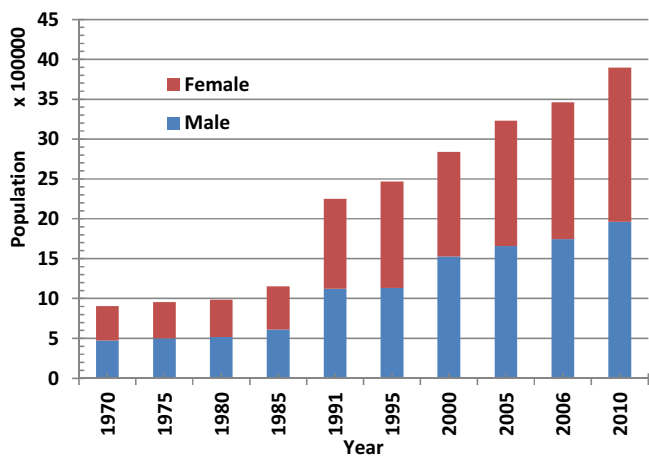

Figure 2. Population of Ondo State Nigeria between 1970 and 2010 (Data used were obtained from National Population Commission, 2004; Draft Digest of Demographic and Vital Statistics of Ondo State)

\section{Materials and methods}

This study uses expository review of secondary datasets from government organizations in Ondo State, Nigeria. The data were assessed and efforts were made to verify some of the claims presented in the published reports from some of the offices, where possible. Data considered include population records from the National Population Commission (NPC) office; records on school attendance from the Ondo State Universal Basic Education Board and 
health records from the State's Ministry of Health and Primary Health Care, all in Akure. Data were subsequently coded and analysed using both quantitative and qualitative approaches.

(a)

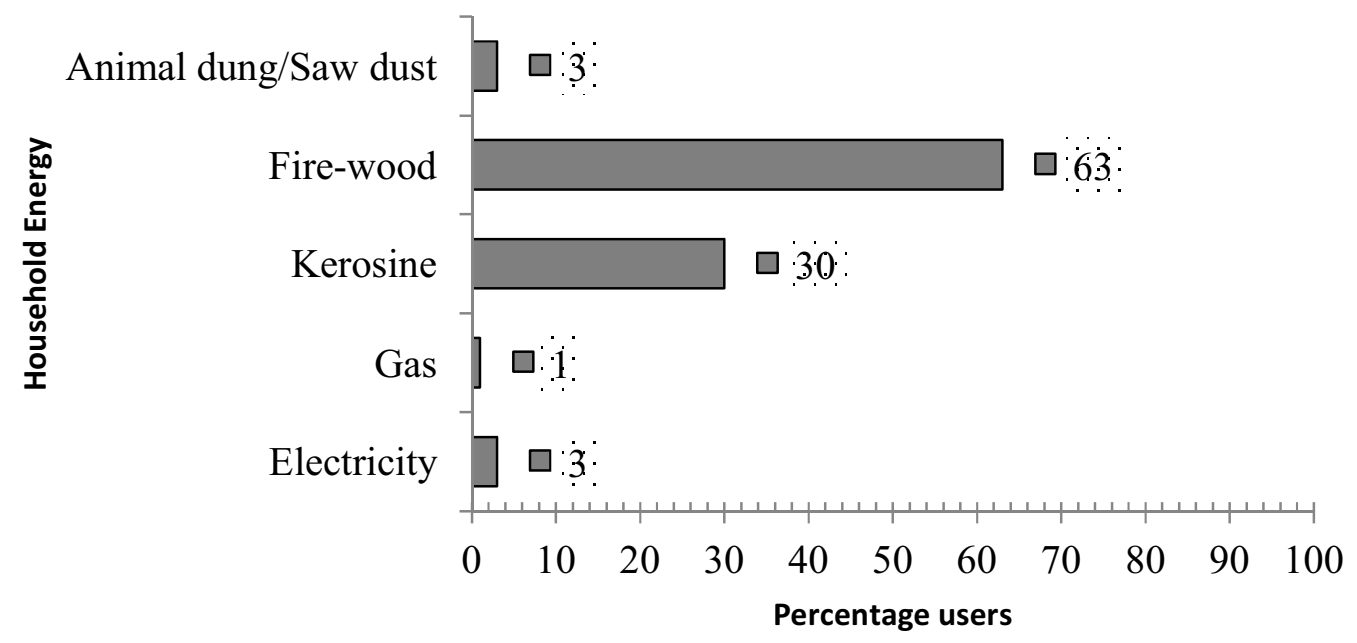

(b)

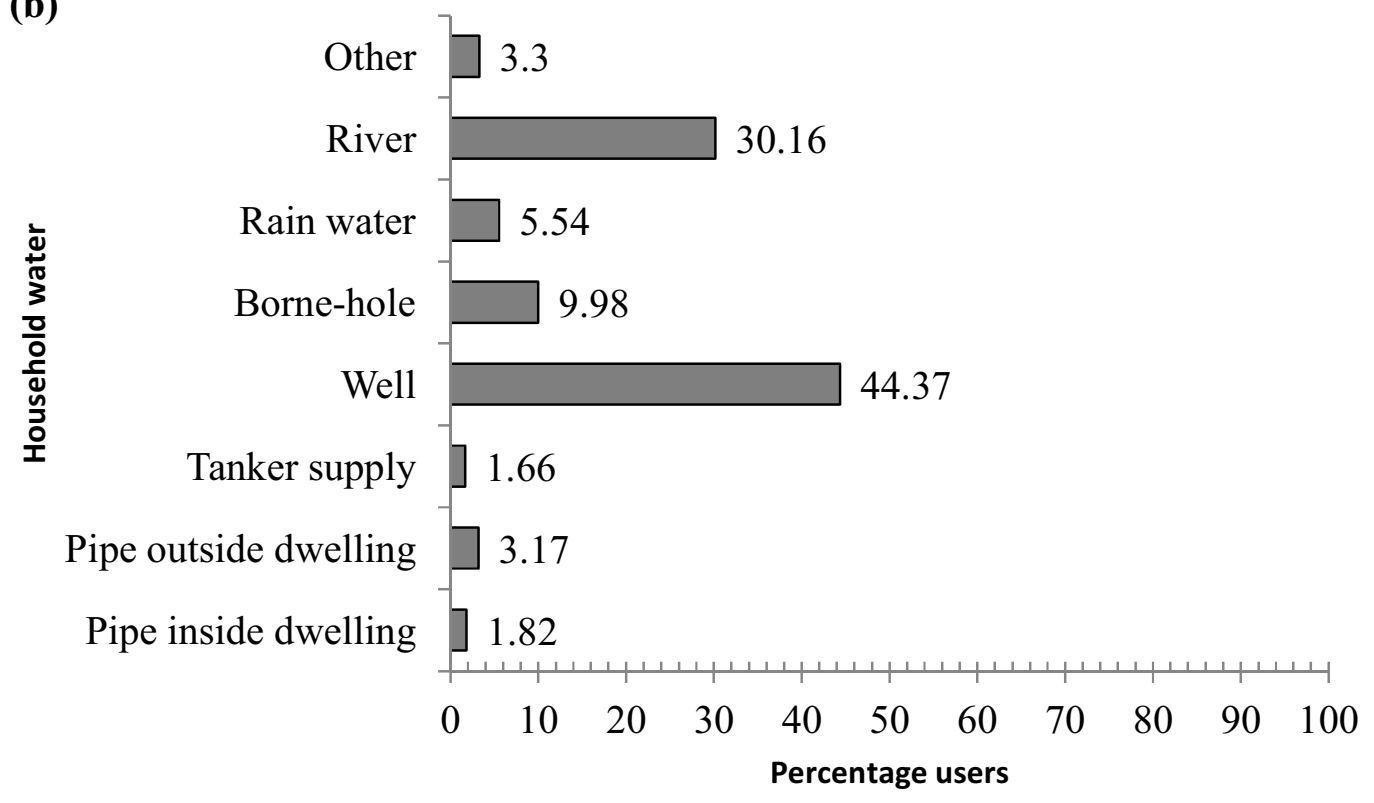

Figure 3: Energy and water use in Ondo State Nigeria; a. energy use, and b. source of domestic water 
Figure 3a-b shows the distribution of energy use and water sources in the study area. $63 \%$ of the total population in Ondo State used firewood as domestic source of energy for cooking, and $30 \%$ made use of kerosene stoves, while less than $5 \%$ used both gas and electricity for energy (Figure 3a). That more than $90 \%$ of the populations of the State still make use of fuelwood and kerosene may not be unconnected with the poor supply of electricity throughout Nigeria. Studies on the Nigerian electricity supply (e.g. Olukoju, 2004) have shown that the Nigerian electricity falls far short of demand, even with many of the reported attempts of the government. The use of gas was the least, only restricted to $1 \%$ of the total population, which are likely to be among the affluent in the society because of the expense involved in gas energy use relative to other sources of domestic energy.

Figure $3 \mathrm{~b}$ shows that about $44.4 \%$ and $30.2 \%$ use source water from hand dug wells and streams, respectively. On the other hand, pipe borne water accounted for water source for less than $5 \%$. The State government had provided boreholes for many of the towns and villages in the local government but the ground trotting information showed that more than $70 \%$ of the boreholes were no longer functioning as a result of poor maintenance.

Infrastructure for household waste disposal

Figure 4a-b shows the distribution of the method of wastewaters and refuse disposal in Ondo State during the time of this study. More than $80 \%$ of the population were shown to use either the crude method of defecating in the bush or use of pit latrine. A pit toilet is a dry toilet system which collects human excrement in a large container and ranges from a simple slit trench to more elaborate systems with ventilation.

Figure $4 \mathrm{~b}$ shows that about $60 \%$ of the State's population either burn their dry wastes at home or dump them in unapproved dumpsites around their houses. About 18\% nonetheless collect their waste for proper disposal while $5 \%$ was reported to buy theirs. In general, it is either that the infrastructure for sanitation was not available or that the people are not aware of its availability.

\section{Infrastructure on basic health}

Table I shows the records of deaths in the State. The highest killer in the State in the period of study was fever (23.9\%), followed by accidents and injuries (I4.1\%). HIV/AIDS killed about $9 \%$ in the State. Table 2 shows that children were immunized against seven killer diseases (BCG, whooping cough, polio, tuberculosis, measles, yellow fever and tetanus) in all the senatorial districts of the State. Subsequently, records showed that only 3 (I male and 2 female) still births and infant mortality occurred within the first 28 days, and 5 within first one year for the period of 1997-2010. The total live births around this period (1997-2010) were 129,877 , suggesting that the rate of infant mortality was very low (less than I per thousand).

\begin{tabular}{|c|c|c|c|}
\hline & Cause of Death & Register death & Percentage \\
\hline 1 & Accidents and Injuries & 164 & 14.05 \\
\hline 2 & $\begin{array}{l}\text { Child birth and } \\
\text { complications from } \\
\text { pregnancy }\end{array}$ & 69 & 5.91 \\
\hline 3 & Digestive disorders & 58 & 4.97 \\
\hline 4 & Urinary disorders & 6 & 0.51 \\
\hline 5 & $\begin{array}{l}\text { Blood circulatory } \\
\text { system's disorder }\end{array}$ & 102 & 8.75 \\
\hline 6 & $\begin{array}{l}\text { Disorder of the } \\
\text { nervous system }\end{array}$ & 51 & 4.37 \\
\hline 7 & $\begin{array}{l}\text { Disorder of the } \\
\text { respiratory system }\end{array}$ & 64 & 5.48 \\
\hline 8 & Fever & 279 & 23.91 \\
\hline 9 & HIV/AIDS & 104 & 8.92 \\
\hline 10 & Other ailments & 136 & 11.65 \\
\hline \multirow[t]{2}{*}{11} & Senility & 134 & 11.48 \\
\hline & Total & 1167 & 100 \\
\hline
\end{tabular}


Table 2 Number of immunized children in Ondo State, Nigeria in 2010 by senatorial districts

\begin{tabular}{lccccccc}
\hline & BCG & $\begin{array}{c}\text { Whooping } \\
\text { Cough }\end{array}$ & Polio & Tuberculosis & Measles & $\begin{array}{c}\text { Yellow } \\
\text { Fever }\end{array}$ & Tetanus \\
\hline Ondo North & 17874 & 31493 & 51189 & 4384 & 18982 & 5778 & 52838 \\
Ondo Central & 26880 & 21455 & 63178 & 517 & 8507 & 11356 & 29773 \\
Ondo South & 40470 & 51238 & 93145 & 10984 & 22037 & 25708 & 22037
\end{tabular}

Source: National Primary Health Care Akure

(a)

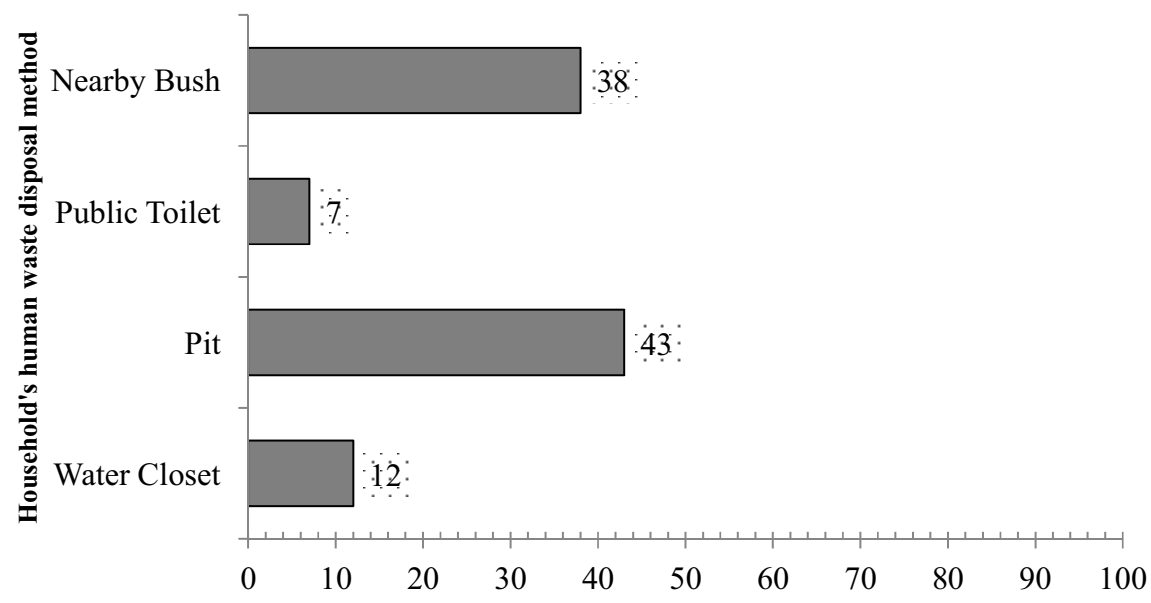

(b)

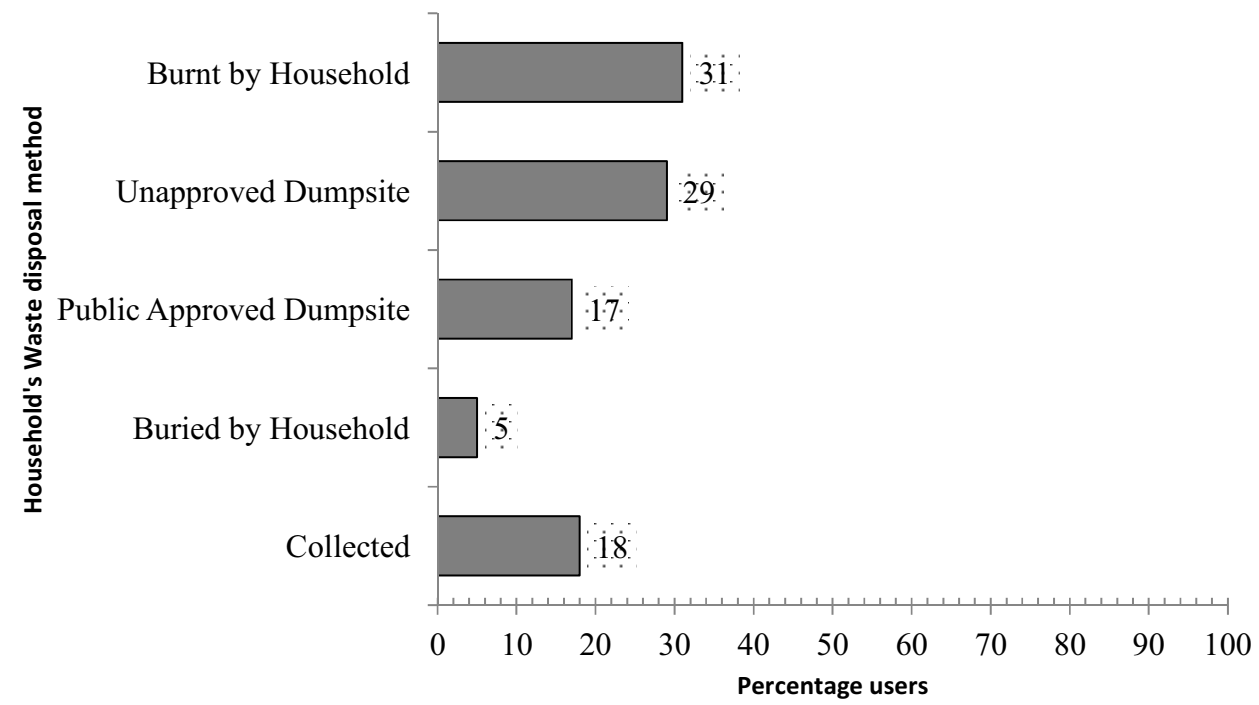

Figure 4. Sanitation in Ondo State, Nigeria; a. wastewater and, b. refuse disposal methods

Programmes of the State government that can be linked with the health sector are the 'Mother and Child Hospital' and 'Abiye Safe Motherhood' which allow pregnant woman in the State free access to medical care. Gbotosho et al (2009) also showed that the State government also set a programme which supplies free drugs, insecti- cide-treated nets, indoor insecticide-spraying and treatments to curb the prevalence of malaria in the State. It was also noted that a State programme also focused on providing care for HIV/AIDS patients through the support of international organizations, particularly the USAID and WHO. 


\section{Education}

In the 2009/2010 school, about 374, 948 primary school pupils were registered in primary schools across Ondo State. The distribution across the three senatorial districts of the State is shown in Table 3. Female pupils were well balanced with the male students; more than $45 \%$. Ondo South Senatorial district recorded about $42.14 \%$ of total pupil registration, and the least was recorded in Ondo Central (28.21\%) (Table 3).

Table 3 Summary of enrolment in public primary schools in Ondo State by Senatorial Districts. 2009/2010 Session

\begin{tabular}{lcccc}
\hline & Male & Female & Total & $\%$ \\
\hline Ondo North & 127800 & 135974 & 263774 & 29.65 \\
Ondo Central & 121470 & 129540 & 251010 & 28.21 \\
Ondo South & 189080 & 185866 & 374948 & 42.14 \\
\hline
\end{tabular}

Source: - SUBEB (State Universal Basic Education Board) Akure

\section{Discussion}

This study was aimed at assessing the relationship between population growth and infrastructure, as well as examining the efforts aimed at achieving the MDGs in a Nigerian State, as an approach to providing preliminary information of analyzing same in more states in Nigeria. Data used for the study were obtained from the statistics available in the State. The study has reported that the population in the study area is increasing annually, as is common to most settlements in developing countries, including Nigeria where this study was carried out. Studies such as the United Nations Environment Programme (2002) have reported increases in urban populations in developing countries, to have grown by about $40 \%$ between from 1975 and that more than 30 billion people will be added to the population of the presently lessdeveloped nations. In Nigeria, the urbanization rate was conservatively put at $5 \%$ as at 1973 (Olowu, 1985) and by 1980 nearly $30 \%$ of the total population was alreadyresiding in urban centres. The Nigerian urban population is known to increase at about $3.8 \%$ annually and the rural population by I.8\% (World Statistics, 20II); the population of Ondo State has however been increasing by $5 \%$ from 1985 to 2010 , as derived from the population data used for this study. The results obtained from the analysis of the statistics on the available infrastructure for domestic energy have shown that the majority $(63 \%)$ of the people of the State use firewood for domestic purposes. The use of fuelwood is peculiar to the State, however. For example, Leach and Mearns (1988) showed that $79 \%$ of the total traditional energy consumed in developing countries is fuelwood and between $60 \%$ and $69 \%$ of this is in sub-Saharan Africa. However, fuelwood use is known to be proportional to forest loss and environmental degradation in the region (Dovie et al., 2004), and it is not a clean energy like electricity and gas. Electricity in Nigeria is controlled by the Federal Government of Nigeria, but the supply is known to fall short of the demand in most parts of the country, including Ondo State (Olukoju, 2004). Gas on the other hand is considered too expensive for most households.

Similarly, the study showed that the main sources of domestic water in the State at the time of the study were wells (44.4\%) and streams $(30.2 \%)$. The water quality from these sources of water is usually known to be low, except when purified because of the influence of land-uses around them (e.g. Eludoyin et al., 2004; Eludoyin et al., 2008). Eludoyin et al. (2004) noted that polluted water (with excess amounts of sulphates, nitrates or any toxic elements) can cause disorders known as catharsis, dehydration and gastro-intestinal irritation in humans. Water with excess concentrations of toxic substances such as lead ion can inhibit the formation of blood cells and also cause brain damage in children (WHO, 1972; Townsend, 1991). Furthermore, analysis of the data on waste disposal in the study area suggests that the majority of the people use pit toilet or do not have a good way of disposing human of waste from the households. Although studies (e.g. Cairncross, 1989) have canvassed the use of pit toilets or mobile toilets in rural areas in poor countries, the sanitation practice in most regions where such methods of disposing 
human wastes prevail is considered to be generally low.

On the other hand, with a record of about 626 health facilities in the State, and distributed around the senatorial districts in the State, Ondo State has obviously shown more commitment in this respect. Specific programmes of the State, including 'Abiye Safe Motherhood' and 'Mother and Child', have apparently reduced the deaths of children and pregnant women in the State. Nonetheless, the mortality rate, especially deaths caused by fever, emergencies and HIV/AIDS, can still be reduced.

\section{Conclusion}

This study has evaluated some the population issues in Ondo State, Nigeria along with the infrastructure within the context of the MDGs in the State. The study has shown that a number of issues are yet to be addressed on energy, sanitation and environment, while steps have been taken in the right direction on health and education in the State. Population in the State, like most regions in Nigeria, shown an increasing trend, but it is unlikely that the present infrastructure is sufficient to sustain the increase. The State government will therefore be required to focus on more development and people-oriented programmes if the desire to meet the millennium development goals is sincere. Furthermore, the information from the energy use suggested that a large population of Ondo State live in the rural area. The UN-HABITAT (2005) recommended that improving the lives of people living in rural areas may provide an important entry point for achieving the MDGs. There is also a need to improve the programmes aimed at reducing poverty and promoting environmental sustainability.

\section{References}

Adeboyejo, A and Abolade, O. 2006. Analysis of Spatial Changes in Ogbomoso City: Journal of the NTP, Vol XIX No I pg 35-47

Aguda, A.S., Farinde, T.A., Adegboyega, S.A. and Olawole, M.O. 2013. Spatio-temporal assessment of urban growth of medium-size and nodal towns for sustainable management: using GIS, Management of Environmental Quality: An International Journal, 24 (I): 94 - 106

Akinbode O, Eludoyin A and Fashae O. 2008. Temperature and relative humidity distributions in a medium-size administrative town in southwest Nigeria, Journal of environmental management 87: 95-105

Cairncross, S. 1989. Water supply and sanitation: an agenda for research. The Journal of tropical medicine and hygiene 92: 301

Dovie, D.B, Witkowski, E and Shackleton, C.M. 2004. The fuelwood crisis in southern AfricaRelating fuel wood use to livelihoods in a rural village, Geojournal 60: 123-133

Eludoyin A, Ofoezie I and Ogunkoya O. 2004. The effect of Oja-titun market effluent on the chemical quality of receiving OPA reservoir in lleIfe, Nigeria. Journal of environmental management 72: 249-259

Eludoyin A. O., Eludoyin O. M., Oyinloye M. A. and Akinbode A. V (2008) Effect of Sanitation Practice on Streams Draining a Medium Size Urban Market in lle-Ife, Nigeria: A Preliminary Study, In: B.S. Richards, A.I. Schäfer, (Eds.) Water and Sanitation in International Development and Disaster Relief, University of Edinburgh, UK, May 2008, 556-563

Eludoyin O.M and Adelekan I.O. 2013. The physiologic climate of Nigeria. International journal of biometeorology 57: 24 I-264

Kuznets, S 2003. Population and Economic Growth" American Philosophical Society Proceedings Vol.2 (2) Pp. 170-193.

Martine G and Marshall A. 2007. State of world population 2007: unleashing the potential of urban growth, United Nations

Moe, C.L and Rheingans, R.D. 2006. Global challenges in water, sanitation and health. Journal of water and health 4: 41

Nunan, F and Satterthwaite, D. 200I. The influence of governance on the provision of urban environmental infrastructure and services for low-income groups. International Planning Studies 6: 409-426

Olowu, D., 1985. Local government and urban development in Nigeria. In: Abiodun, J.O. (Ed.), Urban and Regional Planning Problems in Nigeria. University of Ife Press Ltd., Nigeria, pp. 272-298.

Olukoju, A. 2004. 'Never Expect Power Always'. Electricity consumers' response to monopoly, corruption and inefficient services in Nigeria, African Affairs 103: 5I-7I

Gbotosho, G.O, Happi, C.T, Ganiyu, A, Ogundahunsi, O.A, Sowunmi, A and Oduola, A.M (2009) Potential contribution of prescription practices to the emergence and spread of chloroquine resistance in south-west Nigeria: caution in the use of artemisinin combination therapy. Malar J 8: 313

Ranis G, Stewart F, Ramirez A (2000) Economic 
growth and human development. World development 28: 197-219

Townsend A. 1991. Encyclopedia of Analytical Science, vol. 7, Academic Press, London

UN-Habitat, 2005. Global Urban Observatory, Urban Indicators, Phase III

United Nations Environment Programme, 2002. Global Environment Outlook 3 /www.unep.org/ GEO/geo3/index.htm, 2004-03-03

United Nations Population Fund (UNFPA), 1996. The state of world population, UNFPA, Chap. 3.
URL: http://www.unfpa. org/ch396.html

United Nations, 2008. World population prospects, the 2008 revision, UN Population division New York: United Nations. URL http:// www.un.org/.

United Nations, 2013. The millennium development goals report, UN, http://www.un.org/ millenniumgoals/pdf/report-20/3/mdg-report-20/3english.pdf

WHO, 1972. Health Hazards of Human Environment, WHO, Geneva . 